\title{
Technological Inclusion in Small Coffee Plantations in the South of the State of Minas Gerais, Brazil
}

\author{
Wanêssa Tavares Campos Corsini \\ University Jose do Rosário Vellano (UNIFENAS), School of Agronomy \\ Highway MG 179, Km 0, Postal Code 37132-440, Alfenas, MG, Brazil \\ Federal Institute of Southern Minas Gerais, (IFSULDEMINAS), Campus Machado \\ Highway Machado - Paraguaçu, s/n, Postal Code 37750-000, Machado, MG, Brazil \\ E-mail: wanessa.corsini@ifsuldeminas.edu.br
}

Fábio dos Santos Corsini

University Jose do Rosário Vellano (UNIFENAS), School of Agronomy Highway MG 179, Km 0, Postal Code 37132-440, Alfenas, MG, Brazil Federal Institute of Southern Minas Gerais, (IFSULDEMINAS), Campus Machado Highway Machado - Paraguaçu, s/n, Postal Code 37750-000, Machado, MG, Brazil E-mail: fabio.corsini@ifsuldeminas.edu.br

Marina Ariente Angelocci Anhanguera College, (ANHANGUERA)

Street Senador Fláquer, 456, Center, Postal Code 09010-160, Santo André, SP, Brazil E-mail: msarient@hotmail.com

Luciana de Paula Naves

Federal University of Lavras (UFLA), Department of Animal Science Aquenta Sol, s/n, Postal Code 37200-900, Lavras, MG, Brazil E-mail: luciananaves@ufla.br 
Federal Institute of Southern Minas Gerais, (IFSULDEMINAS), Campus Machado

Highway Machado - Paraguaçu, s/n, Postal Code 37750-000, Machado, MG, Brazil

E-mail: leandro.paiva@ifsuldeminas.edu.br

\author{
Adriano Bortolotti da Silva \\ University Jose do Rosário Vellano (UNIFENAS), School of Agronomy \\ Highway MG 179, Km 0, Postal Code 37132-440, Alfenas, MG, Brazil \\ E-mail: adriano.silva@unifenas.br \\ Bruno César Góes \\ University Jose do Rosário Vellano (UNIFENAS), School of Agronomy \\ Highway MG 179, Km 0, Postal Code 37132-440, Alfenas, MG, Brazil \\ E-mail: bruno.goes@unifenas.br
}

Fernando Ferrari Putti (Corresponding author)

São Paulo State University (UNESP), School of Sciences and Engineering

176 King St: Domingos da Costa Lopes, 780 Jardim Itaipu, Postal Code 17602-496,

Tupã, SP, Brazil

E-mail: fernando.putti@unesp.br

Received: February 21, 2021

Accepted: March 25, 2021 Published: March 26, 2021

doi:10.5296/jas.v9i2.18328

URL: https://doi.org/10.5296/jas.v9i2.18328

\begin{abstract}
World market is increasingly expanding in food production. Coffee has been underscored within the new scenario and positively impacts the economy of the country, together with other crop types. Current analysis assesses the insertion index of new technological resources and the fastness of the production process of coffee culture on small coffee plantations in the south of the state of Minas Gerais, Brazil. Field study comprised the analysis of 225 farms by an open and closed questionnaire. Data, analyzed by cluster analysis, revealed that small farms have invested in technologies and data access technology for harvest and production processing. Corroborating other scientific investigations, the above activity decreased the
\end{abstract}


labor force and consequently triggered an increase in profits for small producers.

Keywords: small producers of coffee, production process, technological resources

\section{Introduction}

World market is making every effort to supply increase in the demand for food products, and entrepreneurs and producers are eager to attend requirements for quality food through all the available methodologies possible (Nitzke et al., 2012; Ramos et al., 2015; Sediyama et al., 2014). Coffee production process in the southern region of the state of Minas Gerais, Brazil, has endeavored to comply with international standards in coffee production (Pereira et al., 2010). As an indirect result of the process, the coffee market has propped Brazilian economy, together with other agricultural products (Barra \& Ladeira, 2016; Dos Santos et al., 2009).

The coffee production region, comprising Machado, Poço Fundo and other neighboring towns in the south of the state of Minas Gerais, has been in the limelight since it is mostly composed of small-sized farms which financially depend on their own production (Frederico, 2013; Frederico; Barone, 2015; Vilela; Rufino, 2010, Cunha and Putti, 2020; Cunha et al., 2017, Gabriel Filho et al., 2017).

Owing to the market's technological evolution, small producers must be in constant evolution to follow state-of-the-art technology. Technological investment has been underscored as the great strengthener in the fastness of the production process and of increase in profits, mainly with regard to decrease in production costs (Amarasinghe et al., 2015; De Assis Silva; et al., 2011; Lima et al., 2016; Perdoná et al., 2012; Ramalho et al., 2016; Rosa et al., 2010; Santinato et al., 2016; Xia et al., 2015). Further, the monitoring of pests which are abundant in the country's coffee plantations also make possible fast control action in the culture (Alves et al., 2011; Lopes et al., 2012).

Current investigation analyzes small coffee farms in the above region with regard to the implementation of new technologies in the coffee production process.

\section{Method}

The methodology employed in current field study (Gil, 2002) comprised a questionnaire with 22 open and closed questions, for data collection, based on themes indicated by a bibliographic survey. The questionnaire was submitted to the Committee for Ethics of the José do Rosário Vellano University (UNIFENAS) and approved by Protocol 62778216.8.0000.5143.

The geographic area was limited to the southern region of the state of Minas Gerais and comprised the following towns: Alfenas, Andradas, Bandeira do Sul, Boa Esperança, Botelhos, Cabo Verde, Campestre, Carvalhópolis, Guaxupé, Jacutinga, Machado, Nepomuceno, Paraguaçu, Poço Fundo, Poços de Caldas, São João da Mata, Silvianópolis and Turvolândia (Figure 1). 


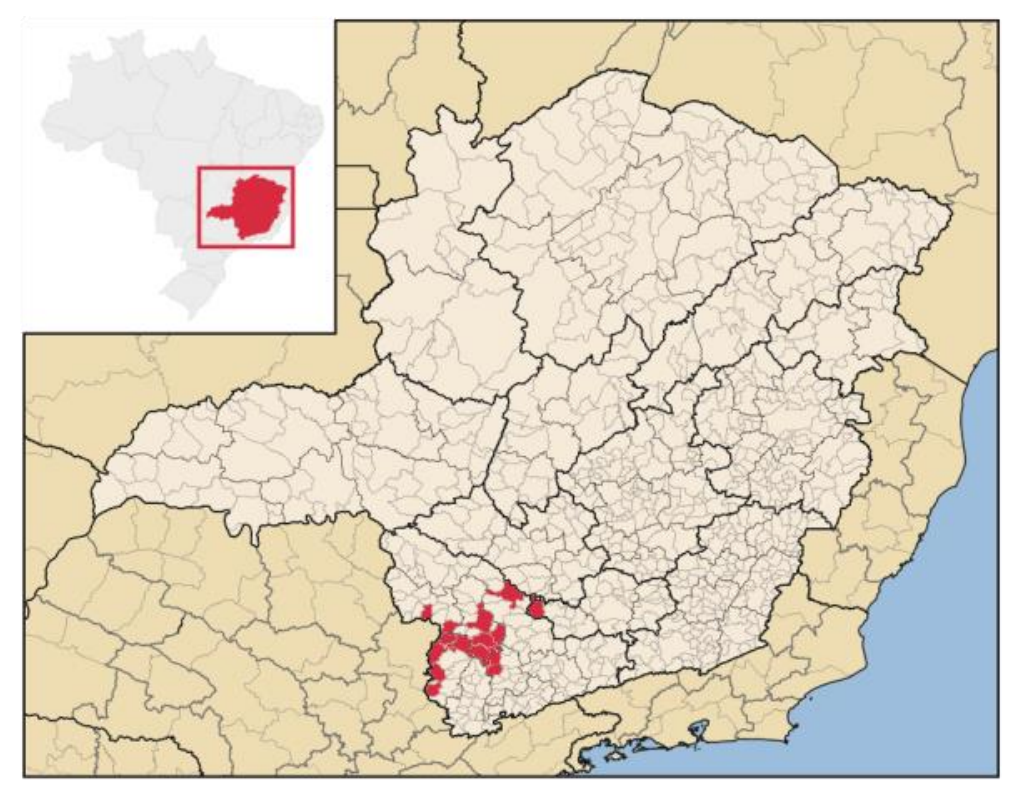

Figure 1. Map of the state of Minas Gerais with the municipalities in which the farms were evaluated

\subsection{Analysis of the Discriminating Cluster}

Cluster analysis was performed to group sampling items and groups with different characteristics. Similar objects are grouped in this type of analysis. For each sampling unit $j$, there is a vector of rates $X_{j}$, with $p=$ variables (Mingoti, 2013).

$$
X_{j}=\left[X_{1 j}, X_{2 j}, \ldots, X_{p j}\right] \text { with } j=1,2,3, \ldots, n .
$$

Where $X_{l j}$ is the rate for $i$ measured in sampling object $j$. Data are transformed according to Euclidian measurements (Mingoti, 2013) and the hierarchical methodology of K-averages was taken into account (Krebs, 1999; Souza \& Souza, 2006).

\subsection{Analysis of Co-relationship}

Pearson's co-relation was employed for a positive or negative relationship between the two elements, at $5 \%$ significance.

\section{Results and Discussion}

Data were presented by four different methodologies: analysis of variables (producer's primary characterization, the farm, type of coffee produced); Pearson's co-relationship of variables; class analysis; cluster (groupings) analysis. Sample comprised 225 filled questionnaires, although, according to the assay's scheme, not all questions were taken into account.

\subsection{Initial Analysis of Data}

Data on the coffee producer in the region under analysis comprise: age (32.44\%, over 54 years old; $16.44 \%$, between 36 and 41 years old; $14.67 \%$, between 42 and 47 years old; $13.33 \%$, between 30 and 35 years old; $12.45 \%$, between 48 and 53 years old; $10.67 \%$, below 
29 years old); schooling level (47.56\%, basic schooling; 28\%, high school; $14.22 \%$, undergraduate degree; $10.22 \%$, postgraduate degree); technical training in agriculture (66.22\% do not have any training in agriculture; $33.78 \%$ have some sort of training).

Most producers interviewed had low schooling level, coupled to low technical training in agriculture. The above is highly important since specialized technical knowledge within the farm's administration process is mandatory (Nagaoka et al., 2011). The age of most interviewed people is an item that should be underscored, namely, (32.44\% were over 54 years old). In fact, they experienced several different events especially with regard to changes in sanitary rules that guide the coffee-producing market (Pereira et al., 2010).

Results on the farms under analysis revealed the following facts: farm size $(44.44 \%$ of the farms were over 9 ha; the size of $25.33 \%$ varied between 3 and 6 ha; $17.33 \%$ varied between 1 and 3 ha; $12.9 \%$ varied between 6 and 9 ha). External consulting services were used by $53.78 \%$ of producers; $51.56 \%$ were not connected with the Internet; $48.44 \%$ were connected; $81 \%$ of producers monitored crop pests; $16 \%$ did not; $3 \%$ did not answer the question. Monitoring periodicity was executed by $50 \%$ between 3 to 6 months; $28 \%$ monitored every 30 days; $21 \%$ once a year; $1 \%$ did not answer).

Farms under analysis could be characterized as small, according to current norms (Incra, 2013), although most owners highly considered specialized consulting services. Farm monitoring was given great care, corroborating with research that underscore such control for the success of the enterprise (Prado \& Dorneles Junior, 2015).

The culture system and the plantation of other crops together with coffee were also assessed. In fact, $86.23 \%$ of farms deal with conventional culture system; $8.44 \%$ deal with organic crop system; $4 \%$ featured a mixture of organic and conventional system; $1.33 \%$ identified their type of crop system as ecological, possibly referring to an agricultural-forest system (De Souza et al., 2014). Data corroborate research that identifies the conventional production system as the most used model in Brazil since the 19th century (Lopes et al., 2012). Intercropping comprised beans, corn, banana, soybean, yams, oil, tobacco, papaya, graviola, passion flower, honey and roses. Cultures actually increased family earnings or one's own consumption.

\subsection{Relationship Between the Variables}

A further perspective of the analysis, assessment was performed following Pearson's co-relationship (Table 1). 
Table 1. Matrix of Pearson's co-relation with regard to questions proposed

\begin{tabular}{|c|c|c|c|c|c|c|c|c|c|c|c|c|c|c|c|c|c|c|c|c|}
\hline & $\stackrel{8}{8}$ & 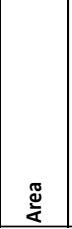 & 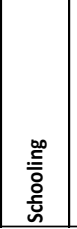 & 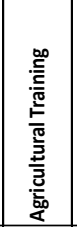 & 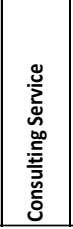 & 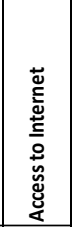 & 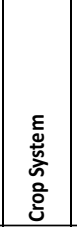 & 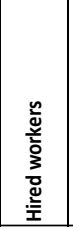 & 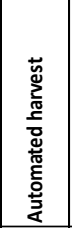 & 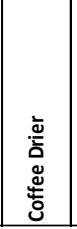 & 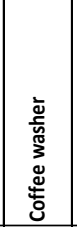 & 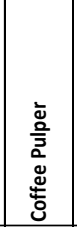 & 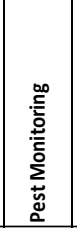 & 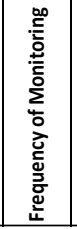 & 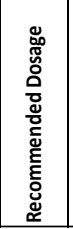 & 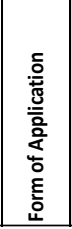 & 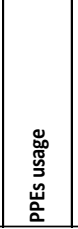 & 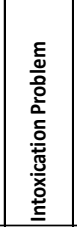 & 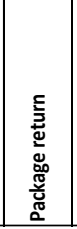 & 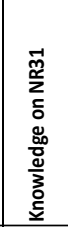 \\
\hline Age & 1 & 0.129 & -0.109 & 0.186 & -0.032 & 0.230 & 0.159 & 0.054 & -0.066 & 0.101 & 0.019 & -0.068 & 0.020 & 0.066 & 0.080 & 0.037 & -0.042 & -0.086 & -0.012 & 0.070 \\
\hline Area & 0.129 & 1 & 0.301 & -0.055 & -0.098 & -0.083 & 0.055 & 0.463 & -0.007 & -0.360 & -0.467 & -0.203 & -0.164 & -0.229 & -0.016 & -0.073 & 0.030 & -0.012 & -0.081 & -0.080 \\
\hline Schooling & -0.109 & 0.301 & 1 & -0.438 & -0.032 & -0.142 & 0.028 & 0.463 & -0.143 & -0.192 & -0.239 & -0.194 & -0.199 & -0.157 & 0.009 & -0.005 & -0.015 & 0.065 & -0.024 & -0.131 \\
\hline Agricultural Training & 0.186 & -0.055 & -0.438 & 1 & -0.035 & 0.173 & -0.080 & -0.175 & 0.116 & 0.052 & 0.101 & -0.003 & 0.110 & -0.004 & 0.024 & 0.084 & -0.024 & -0.003 & 0.028 & 0.215 \\
\hline Consulting Service & -0.032 & -0.098 & -0.032 & -0.035 & 1 & 0.114 & 0.089 & -0.051 & 0.002 & 0.183 & 0.150 & 0.105 & 0.099 & 0.130 & 0.051 & 0.077 & 0.063 & -0.056 & 0.076 & 0.127 \\
\hline Access to Internet & 0.230 & -0.083 & -0.142 & 0.173 & 0.114 & 1 & 0.034 & -0.098 & 0.017 & 0.144 & 0.107 & 0.062 & 0.050 & 0.057 & -0.007 & 0.010 & 0.026 & -0.103 & -0.007 & 0.255 \\
\hline Crop System & 0.159 & 0.055 & 0.028 & -0.080 & 0.089 & 0.034 & 1 & 0.047 & -0.075 & 0.002 & -0.063 & -0.030 & -0.182 & 0.024 & 0.000 & -0.045 & -0.058 & -0.145 & -0.148 & -0.037 \\
\hline Hired workers & 0.054 & 0.463 & 0.463 & -0.175 & -0.051 & -0.098 & 0.047 & 1 & -0.303 & -0.310 & -0.420 & -0.305 & -0.168 & -0.144 & -0.019 & -0.029 & 0.038 & 0.045 & -0.014 & -0.129 \\
\hline Automated harvest & -0.066 & -0.007 & -0.143 & 0.116 & 0.002 & 0.017 & -0.075 & -0.303 & 1 & 0.120 & 0.212 & 0.200 & 0.119 & 0.103 & 0.077 & 0.074 & 0.007 & 0.044 & 0.069 & 0.196 \\
\hline Coffee Drier & 0.101 & -0.360 & -0.192 & 0.052 & 0.183 & 0.144 & 0.002 & -0.310 & 0.120 & 1 & 0.495 & 0.233 & -0.013 & 0.201 & 0.110 & 0.109 & -0.025 & -0.187 & 0.162 & 0.217 \\
\hline Coffee washer & 0.019 & -0.467 & -0.239 & 0.101 & 0.150 & 0.107 & -0.063 & -0.420 & 0.212 & 0.495 & 1 & 0.394 & 0.090 & 0.122 & 0.033 & 0.180 & -0.017 & -0.117 & 0.100 & 0.212 \\
\hline Coffee P & -0.068 & -0.203 & -0.194 & -0.003 & 0.105 & 0.062 & -0.030 & -0.305 & 0.200 & 0.233 & 0.394 & 1 & 0.122 & 0.170 & 0.053 & -0.133 & 0.057 & -0.050 & 0.042 & 0.070 \\
\hline Pest Monitorin & 0.020 & -0.164 & -0.199 & 0.110 & 0.099 & 0.050 & -0.182 & -0.168 & 0.119 & -0.013 & 0.090 & 0.122 & 1 & 0.000 & 0.215 & 0.015 & 0.135 & -0.085 & 0.134 & 0.116 \\
\hline Frequency of Monitoring & 0.066 & -0.229 & -0.157 & -0.004 & 0.130 & 0.057 & 0.024 & -0.144 & 0.103 & 0.201 & 0.122 & 0.170 & 0.000 & 1 & -0.017 & 0.081 & -0.057 & -0.054 & 0.113 & 0.159 \\
\hline Recommended Dosage & 0.080 & -0.016 & 0.009 & 0.024 & 0.051 & -0.007 & 0.000 & -0.019 & 0.077 & 0.110 & 0.033 & 0.053 & 0.215 & -0.017 & 1 & -0.047 & 0.020 & -0.219 & 0.136 & 0.070 \\
\hline Form of Application & 0.037 & -0.073 & -0.005 & 0.084 & 0.077 & 0.010 & -0.045 & -0.029 & 0.074 & 0.109 & 0.180 & -0.133 & 0.015 & 0.081 & -0.047 & 1 & -0.025 & -0.032 & 0.024 & 0.087 \\
\hline PPEs usage & -0.042 & 0.030 & -0.015 & -0.024 & 0.063 & 0.026 & -0.058 & 0.038 & 0.007 & -0.025 & -0.017 & 0.057 & 0.135 & -0.057 & 0.020 & -0.025 & 1 & 0.020 & 0.154 & 0.041 \\
\hline Intoxication Problem & -0.086 & -0.012 & 0.065 & -0.003 & -0.056 & -0.103 & -0.145 & 0.045 & 0.044 & -0.187 & -0.117 & -0.050 & -0.085 & -0.054 & -0.219 & -0.032 & 0.020 & 1 & 0.027 & -0.152 \\
\hline Package return & -0.012 & -0.081 & -0.024 & 0.028 & 0.076 & -0.007 & -0.148 & -0.014 & 0.069 & 0.162 & 0.100 & 0.042 & 0.134 & 0.113 & 0.136 & 0.024 & 0.154 & 0.027 & 1 & 0.059 \\
\hline Knowledge on NR31 & 0.070 & -0.080 & -0.131 & 0.215 & 0.127 & 0.255 & -0.037 & -0.129 & 0.196 & 0.217 & 0.212 & 0.070 & 0.116 & 0.159 & 0.070 & 0.087 & 0.041 & -0.152 & 0.059 & \\
\hline
\end{tabular}

\subsection{Technologies in Harvesting and Crop Processing}

There was a negative co-relation between the number of farm employees and the variables automated harvest $(-0.303)$, coffee drier $(r=-0.310 ; p=0.05)$, coffee washer $(r=-0.420, p=$ $0.05)$ and coffee pulp machine $(\mathrm{r}=-0.305, \mathrm{p}=0.05)$. Technologies in the production process decreases costs and, consequently, profit increase for producers (Santinato et al., 2016; Xia et al., 2015).

Data analysis also identified a positive co-relation between the introduction of new technologies (coffee drier $-r=0.183, p=0.05$ and coffee washer $-r=0.150 ; p=0.05$ ) and demand for external consulting services. When the farmer is updated technologically, there is also a demand for specialized knowledge on the equipments used.

Another interesting characteristic derived from the data is that the introduction of one of the technologies analyzed has a positive co-relation with the others.

There was a positive co-relation between schooling level and the farm area $(\mathrm{r}=0.301 ; \mathrm{p}=$ 0.05). Analyses also showed a positive co-relation with regard to the number of employees on the farm $(r=0.463 ; p<0.0001)$. Data analysis reveals the impact of job generation on farms when there is an increase in schooling level. Investment on siblings' education is highly appreciated since they may administer the farm and shun being used as mere force labor to the detriment of higher schooling (Frederico \& Barone, 2015).

Corroborating analysis above, an increase in the number of employees has a negative co-relation with technologies employed (coffee drier $-\mathrm{r}=-0.360, \mathrm{p}=0.05$, coffee washer $-\mathrm{r}$ $=-0.467, \mathrm{p}=0.05$, coffee pulp machine $-\mathrm{r}=0.203, \mathrm{p}=0.05)$.

Another characteristic shown in the survey revealed that increase in farm area decreased the monitoring of pests $(r=-0.164, p=0.05)$ and its frequency $(r=-0.229, p=0.05)$. In fact, 
increase in farm area makes difficult the monitoring process with higher pest risks due to their presence on all farms (Vilela \& Rufino, 2010).

\subsection{Analysis of Classes}

So that results could be made easier, data were divided into four different classes (Table 2).

Table 2. Relation of classes and their compatible variables identified in the research data

\begin{tabular}{|c|c|c|c|c|}
\hline Class & 1 & 2 & 3 & 4 \\
\hline Producers & 25 & 15 & 24 & 20 \\
\hline Age (years) & $36-41$ & $30-35$ & over 54 & over 54 \\
\hline Farm area & $*$ & over 9 ha & over 9 ha & over 9 ha \\
\hline Access to the Internet & $*$ & yes & No & yes \\
\hline Schooling level & Basic & $*$ & Basic & Undergraduate \\
\hline Crop system & Conventional & Conventional & Conventional & Conventional \\
\hline Employees & No & $*$ & No & No \\
\hline Agricultural training & No & yes & $*$ & No \\
\hline Automated harvest & Yes & yes & yes & Yes \\
\hline Coffee bean drier & Yes & yes & yes & Yes \\
\hline Coffee bean washer & Yes & $*$ & yes & Yes \\
\hline Coffee pulp machine & Yes & yes & yes & Yes \\
\hline Monitoring & $3-6$ months & $3-6$ months & 30 days & $3-6$ months \\
\hline Consulting services & $*$ & * & yes & Yes \\
\hline
\end{tabular}




\subsection{Cluster Analysis (Groupings)}

Two groups may be underscored in grouping. The first group related investment in consulting services to frequency of farm monitoring. Results show the importance of an external support in the administration and control on farms (Embrapa, 2004; Prado \& Dorneles Junior, 2015).

Corroborating Pearson's co-relation, the relation between harvest automation, the number of employees, coffee bean drier, washer and pulp machine on the farm and pest monitoring is another item that should be underscored. It must be emphasized that investment in technology in coffee production decreased external labor force on small farms and, consequently, an increase in profit (Perdoná et al., 2012; Sette et al., 2010; XIA et al., 2015). Such activity underscores the labor of small farmers with coffee plantation as their main income (Frederico, 2013; Frederico \& Barone, 2015; Vilela \& Rufino, 2010).

Increase in the monitoring of coffee plantations and investment in new technologies is a highly important item. The above activity enhances profit since it avoids losses caused by pests usually found in coffee plantations (Alves et al., 2011; Androcioli, 2010; Lopes et al., 2012).

\section{Conclusion}

Results reveal the validity of investments in technologies for the automation of farm labor. There is a trend that farms using technology in their administration, harvest and processing decrease the number of employees. This fact decreases costs and, consequently, increases profits for the small farm producer.

Farm monitoring is more focused upon when automation is implemented. Results indicate that automation provided a fast harvest and processing which provide farmers with more time for other administrative activities.

\section{Acknowledgments}

José do Rosário Vellano University - UNIFENAS; Federal Institute of Southern Minas Gerais, IFSULDEMINAS - Campus Machado; Poço Fundo Family Farmers' Cooperative, COOPFAM; Technical Assistance and Rural Extension Company - EMATER-MG (Machado / MG and Poço Fundo / MG); Machado Agrarian Cooperative - COOPAMA; and Minas Gerais State Research Support Foundation - FAPEMIG.

\section{References}

Alves, D. S., Oliveira, D. F., Carvalho, G. A., \& Santos, M. A. I. (2011). Extrato de Coffea racemosa como alternativa no controle do bicho-mineiro do cafeeiro. Ciencia $e$ Agrotecnologia, 35(2), 250-258. https://doi.org/10.1590/S1413-70542011000200004

Amarasinghe, U. A., Hoanh, C. T., D’haeze, D., \& Hung, T. Q. (2015). Toward sustainable coffee production in Vietnam: More coffee with less water. Agricultural Systems, 136, 96-105. https://doi.org/10.1016/j.agsy.2015.02.008

Androcioli, H. G. (2010). Controle do bicho-mineiro e de doenças do cafeeiro com insumos 
potenciais para o sistema orgânico. Universidade Estadual de Londrina.

Assis Silva, S., Souza Lima, J. S., \& Oliveira, R. B. (2011). Modelo agrometeorológico na estimativa da produtividade de duas variedades de café arábica considerando a variabilidade espacial. IRRIGA, 16(1), 1-10.

Barra, G. M. J., \& Ladeira, M. B. (2016). Teorias institucionais aplicadas aos estudos de sistemas agroindustriais no contexto do agronegócio café: Uma análise conceitual. REGE Revista de Gestão, 23(2), 159-171. https://doi.org/10.1016/j.rege.2015.12.005

Cunha, A C, \& Putti, F. F. (2020). Nível de aceitação da tecnologia da informação por produtores rurais. Revista Brasileira de Engenharia de Biossistemas,14(3),264-273. https://doi.org//dx.doi.org/10.18011/bioeng2020v14n3p264-273

Cunha, A. C., Florentino, L. A., Silva, A. B. da, Gabriel Filho, L. R. A., \& Putti, F. F. (2017). Sistema computacional web para controle de gestão da produção de café. Coffe Science, 12(3),344-354.

http://www.coffeescience.ufla.br/index.php/Coffeescience/article/view/1291/pdf_1291

dos Santos, V. E., Gomes, M. F. M., Braga, M. J., \& Ramos Silveira, S. D. F. (2009). Análise do setor de produção e processamento de café em Minas Gerais: Uma abordagem matriz insumo-produto. Revista de Economia e Sociologia Rural, 47(2), 363-388. https://doi.org/10.1590/S0103-20032009000200003

Embrapa. (2004). Sistemas Agroflorestais (SAFs), 2004. EMBRAPA. https://www.embrapa.br/busca-de-produtos-processos-e-servicos/-/produto-servico/112/siste mas-agroflorestais-safs

Frederico, S. (2013). Cafeicultura Científica Globalizada e as Montanhas Capixabas: A produção de café Arábica nas regiões do Caparaó e Serrana do Espírito Santo. Revista Sociedade \& Natureza, 25(1), 7-20.

Frederico, S., \& Barone, M. (2015). Globalização E Cafés Especiais: A Produção Do Comércio Justo Da Associação Dos Agricultores Familiares Do Córrego D’Antas-Assodantas, Poços De Caldas (Mg). Sociedade \& Natureza, 27(3), 393-404.

Gabriel Filho, L. R. A., Putti, F. F., Cremasco, C. P., bordin, D., Chacur, M. G. M., \& Gabriel, L. R. A. (2016). Software to assess beef cattle body mass through the fuzzy body mass index. Engenharia Agrícola, 36(1), 179-193. https://doi.org/10.1590/1809-4430-Eng.Agric.v36n1p179-193/2016

Gil, A. C. (2002). Como elaborar projetos de pesquisa. In São Paulo (4.). Atlas.

Incra. (2013). Sistema Nacional de Cadastro Rural: Índices básicos de 2013, 2013. Instituto Nacional de Colonização e Reforma Arária. http://www.incra.gov.br/sites/default/files/uploads/estrutura-fundiaria/regularizacao-fundiaria/ indices-cadastrais/indices_basicos_2013_por_municipio.pdf

Krebs, C. J. (1999). Ecological Methodology. In the Benjamin/Cummings series in the life 
sciences (2 nd). Harper \& Row. https://doi.org/10.1007/s007690000247

Lima, J. S. S., Silva, S. A., Oliveira, R. B., \& Fonseca, A. S. (2016). Estimativa da produtividade de café conilon utilizando técnicas de cokrigagem. Revista Ceres, 63(1), 54-61. https://doi.org/10.1590/0034-737X201663010008

Lopes, P. R., Araújo, K. C. S., Ferraz, J. M. G., Lopes, I. M., \& Fernandes, L. G. (2012). Produção de café agroecológico no sul de Minas Gerais: Sistemas alternativos à produção intensiva em agroquímicos Producing agroecological coffee in Southern Minas Gerais: Alternative systems for inten. Revista Brasileira de Agroecologia, 7(1), 25-38.

Mingoti, S. A. (2013). Análise de dados através de métodos de estatística multivariada: Uma abordagem aplicada. UFMG.

Nagaoka, M. P. T., Ensslin, L., Ensslin, S. R., \& Nagaoka, A. K. (2011). Gestão de propriedades rurais: processo estruturado de revisão de literatura e análise sistêmica. Revista Brasileira de Agrociência, 17(4), 410-419.

Nitzke, J. A., Thys, R., Martinelli, S., Oliveiras, L. Y., Augusto-Ruiz, W., Penna, N. G., \& Noll, I. B. (2012). Segurança alimentar: Retorno às origens? Brazilian Journal of Food Technology, 15(spe), 2-10. https://doi.org/10.1590/S1981-67232012005000044

Perdoná, M. J., Soratto, R. P., Martins, A. N., Suguino, E., \& Mancuso, M. A. C. (2012). Irrigação e certificação da cafeicultura na região Centro-Oeste de São Paulo. Bragantia, 71(3), 377-384. https://doi.org/10.1590/S0006-87052012005000034

Pereira, V. F., Vale, S. M. L. R., Braga, M. J., \& Rufino, J. L. S. (2010). Riscos e Retornos da Cafeicultura em Minas Gerais: Uma análise de custos e diferenciação. Revista de Economia e Sociologia Rural, 48(3), 657-678. https://doi.org/10.1590/S0103-20032010000300008

Prado, S. S., \& Dorneles Junior, J. (2015). Principais pragas do cafeeiro no contexto do manejo integrado de pragas, 2015. EMBRAPA MEIO AMBIENTE. https://www.embrapa.br/tema-integracao-lavoura-pecuaria-floresta-ilpf/busca-de-noticias/-/n oticia/6694669/artigo---principais-pragas-do-cafeeiro-no-contexto-do-manejo-integrado-de-p ragas

Ramalho, A. R., Rocha, R. B., Souza, F. F., Veneziano, W., \& Teixeira, A. L. (2016). Progresso genético da produtividade de café beneficiado com a seleção de clones de cafeeiro 'Conilon'1. Revista Ciencia Agronomica, 47(3), 516-523. https://doi.org/10.5935/1806-6690.20160062

Ramos, M. R., Favaretto, N., Uhlmann, A., Dieckow, J., Vezzan, F., \& Almeida, L. (2015). Produção de hortaliças no sistema orgânico: Efeito nos atributos físicos do solo. Amazonian Journal of agricultural and Environmental Sciences, 58(1), 45-51. http://dx.doi.org/10.4322/rca.1666 Michele

Rosa, V. G. C., Moreira, M. A., Rudorff, B. F. T., \& Adami, M. (2010). Estimativa da produtividade de café com base em um modelo agrometeorológico-espectral. Pesquisa Agropecuária Brasileira, $45(12)$, 1478-1488. 
https://doi.org/10.1590/S0100-204X2010001200020

Santinato, F., Silva, R. P., Silva, V. A., Silva, C. D., \& Tavares, T. O. (2016). Mechanical Harvesting of Coffee in High Slope 1. Revista Caatinga, 29(3), 685-691. http://dx.doi.org/10.1590/1983-21252016v29n319rc

Sediyama, M. A. N., Santos, I. C., \& Lima, P. C. (2014). Cultivo de hortaliças no sistema orgânico. Revista Ceres, $\quad$ 61(suppl), https://doi.org/10.1590/0034-737x201461000008

Sette, R. S., Andrade, J. G., \& Teixeira, J. E. R. L. (2010). Planejamento e Gestão da Propriedade Cafeeira. UFLA.

Souza, A. L., \& Souza, D. R. (2006). Análise multivariada para estratificação volumétrica de uma floresta ombrófila densa de terra firme, Amazônia Oriental. Revista Árvore, 30(1), 49-54. https://doi.org/10.1590/S0100-67622006000100007

Souza, M. S., Silva, A. A., Teixeira, C. A. D., \& Costa, J. N. M. (2014). Parasitismo na população da broca-do-café Hypothenemus hampei (Ferrari) (Coleoptera: Scolytidae), pelo parasitoide Cephalonomia stephanoderis Betrem (Hymenoptera: Bethylidae). EntomoBrasilis, 7(3), 178-182. https://doi.org/10.12741/ebrasilis.v7i3.402

Vilela, P., \& Rufino, J. (2010). Caracterização da cafeicultura de montanha de Minas Gerais. In Estudos INAES e FAPEMIG. Cadeias Produtivas. Café: Vol. I. INAES.

Xia, X., Qiu, Y., Hu, L., \& Zhou, G. (2015). Application of information technology on traceability system for agro-food quality and safety. IFIP Advances in Information and Communication Technology, 452, 257-269. https://doi.org/10.1007/978-3-319-19620-6_32

\section{Copyright Disclaimer}

Copyright for this article is retained by the author(s), with first publication rights granted to the journal.

This is an open-access article distributed under the terms and conditions of the Creative Commons Attribution license (http://creativecommons.org/licenses/by/4.0/). 